\title{
EFFECTS OF DOPAMINE ANTAGONISTS ON RECEPTIVE FIELDS OF BRISK CELLS AND DIRECTIONALLY SELECTIVE CELLS IN THE RABBIT RETINA ${ }^{1}$
}

\author{
RALPH J. JENSEN ${ }^{2}$ AND NIGEL W. DAW \\ Department of Physiology and Biophysics, Washington University School of Medicine, St. Louis, Missouri 63110
}

Received January 13, 1984; Revised June 7, 1984; Accepted July 9, 1984

\begin{abstract}
The effects of dopamine antagonists on the extracellularly recorded activity of ON- and OFF-center brisk ganglion cells and ON-OFF directionally selective ganglion cells in the rabbit retina were investigated. Haloperidol, fluphenazine, and cis-flupenthixol, infused in the arterial system supplying the eye, produced similar effects. In general, these drugs reduced the antagonistic surround responses of brisk ganglion cells, reduced the sustained excitation of the center response of ON-center brisk-sustained cells, reduced the leading edge response of ON-OFF directionally selective cells to moving light stimuli along with any sustained excitation to stationary light stimuli, and affected the spontaneous activity of the cells. These drug effects appear to be due to a blockade of D-1 (adenylate cyclase-linked) receplors and not to D-2 receptors. Neither $S$-sulpiride nor metoclopramide, two specific D-2 antagonists, had much effect. The findings are the first to describe the functional effects of dopamine antagonists on single cells in the mammalian retina and on ganglion cell activity in the vertebrate retina.
\end{abstract}

Dopamine is the principal catecholamine of the vertebrate retina. In the rabbit, cat, and cynomolgus monkey, dopamine is confined to a class of anacrine cell which makes conlact only with other amacrine cells in the inner plexiform layer (IPL) (Dowling and Ehinger, 1978b; Holmgren, 1982; Holmgren-Taylor, 1982; Pourcho, 1982). Dopaminergic neurons in the goldfish and Cebus monkey, in addition to contacting only other amacrine cells in the IPL, send processes to the outer plexiform layer to contact both horizontal cells and bipolar cells (Dowling and Ehinger, 1978a; Dowling et al., 1980). Dopamine receptors, linked to the enzyme adenylate cyclase, have been found in all vertebrate retinas examined (Brown and Makman, 1973; Bucher and Schorderet, 1975; Watling et al., 1979). According to the classification of Kebabian and Calne (1979), these are D-1 receptors. In addition to these receptors, D-2 receptors (not linked to adenylate cyclase) have also been described in retinas of several species (Watling and Iversen, 1981; Makman et al., 1982; Ventura et al., 1984), including rabbit (Dubocovich and Weiner, 1981).

Studies using single-cell recordings to examine the functional role of the neurotransmitter dopamine in the vertebrate retina have focused primarily on the effects of exogenous dopamine. In the fish retina, dopamine has been shown to decrease the surround responses of bipolar cells (Hedden and Dowling, 1978), to depolarize transient amacrine cells without changing their response much (Hedden and Dowling, 1978), and to decrease the size of the receptive fields of horizontal cells

\footnotetext{
${ }^{1}$ This work was supported by National Institutes of Health Grant EY 00053 to N. W. L. and a fellowship to R. J. J., National Institutes of Health Training Grant EY 07057.

2 To whom correspondence should be addressed.
}

(Negishi and Drujan, 1979; Laufer et al., 1981; Teranishi et al., 1984). This latter effect has also been described in the turtle retina (Neyton et al., 1982). In the isolated rabbil retina, Ames and Pollen (1969) found that dopamine increases the spontaneous activity of OFF-center ganglion cells and decreases the spontaneous and light-evoked responses of ON-center ganglion cells and ON-OFF ganglion cells. In the cat retina, Straschill and Perwein (1975) and, recently, Thier and Alder (1984) have found that iontophoretically applied dopamine decreases the spontaneous activity and light-evoked responses of all ganglion cells regardless of cell type. Thier and Alder (1984) have reported, in addition, that dopamine shifts the center-surround balance of receptive fields of ganglion cells in favor of the center.

The present in vivo study on the rabbit retina was performed to study the effects of dopamine antagonists on ganglion cell recordings - to observe what happens to the receptive field properties of ganglion cells when dopaminergic transmission within the retina is blocked. In this paper we show that dopamine antagonists produce a marked shift in the center-surround balance of brisk ganglion cells in favor of the center. In addition, we observed a dramatic effect that has not been reported in any other retina: dopamine antagonists change the sustained ON response found in some ON-center ganglion cells and ONOFF directionally selective cells into a sustained inhibition. A preliminary account of portions of this work has been given previously (Jensen and Daw, 1983).

\section{Materials and Methods}

The results are based on recordings from 45 adult pigmented rabbits, weighing 2.5 to $3.5 \mathrm{~kg}$. In early experiments the animals were anesthetized with $0.5 \%$ halothane (Fluothane, Ayerst) in a $66 \%$ nitrous oxide, $34 \%$ oxygen mixture. During surgery the halothane was increased to 


\section{Control}

\section{Haloperidol}

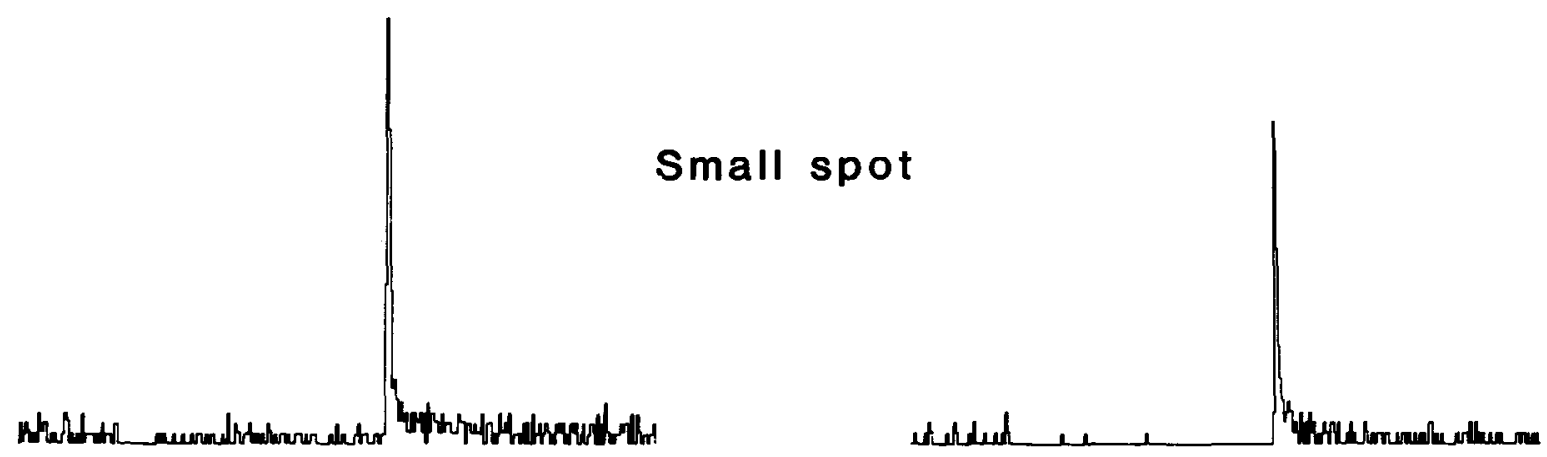

\section{Large spot}
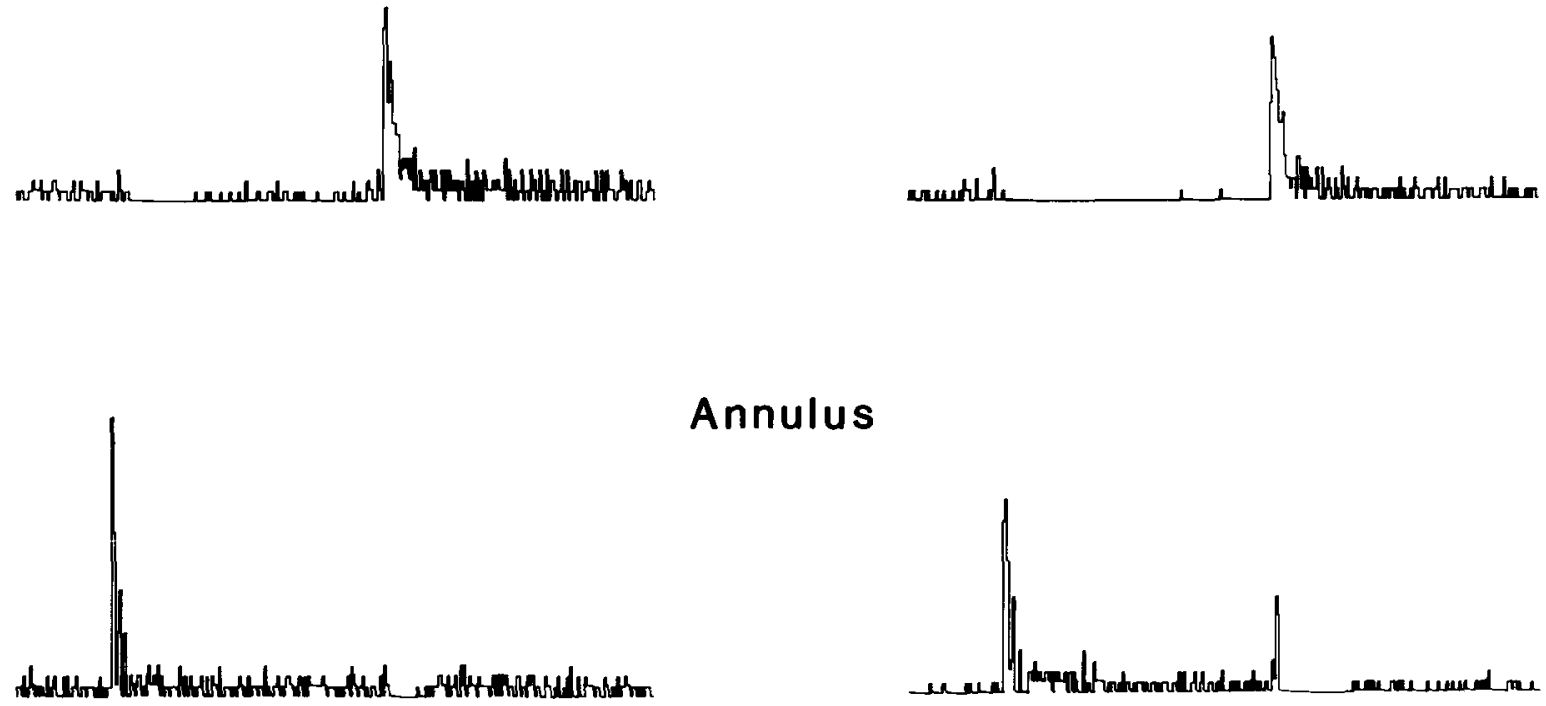

Annulus

Allom

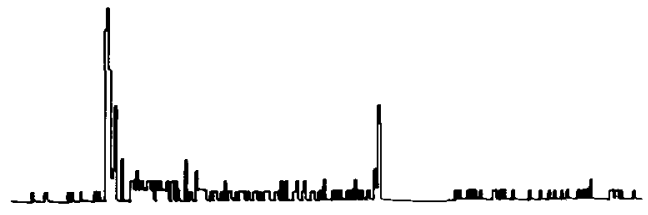

$2 \mathrm{sec}$

Figure 1. Effect of haloperidol on an OFF-center brisk cell. Control and drug responses are to a small spot (2.0 degrees ${ }^{2}$, a large spot (18 degrees $^{2}$ ), and an annulus (inner diameter, 2.7 degrees; outer diameter, 18 degrees) of light. Haloperidol decreased the spontaneous activity and shifted the center-surround balance in favor of the center. Histograms, for this and subsequent figures, are the average of four repelitions of the stimulus. 


\section{Control}

\section{Haloperidol}

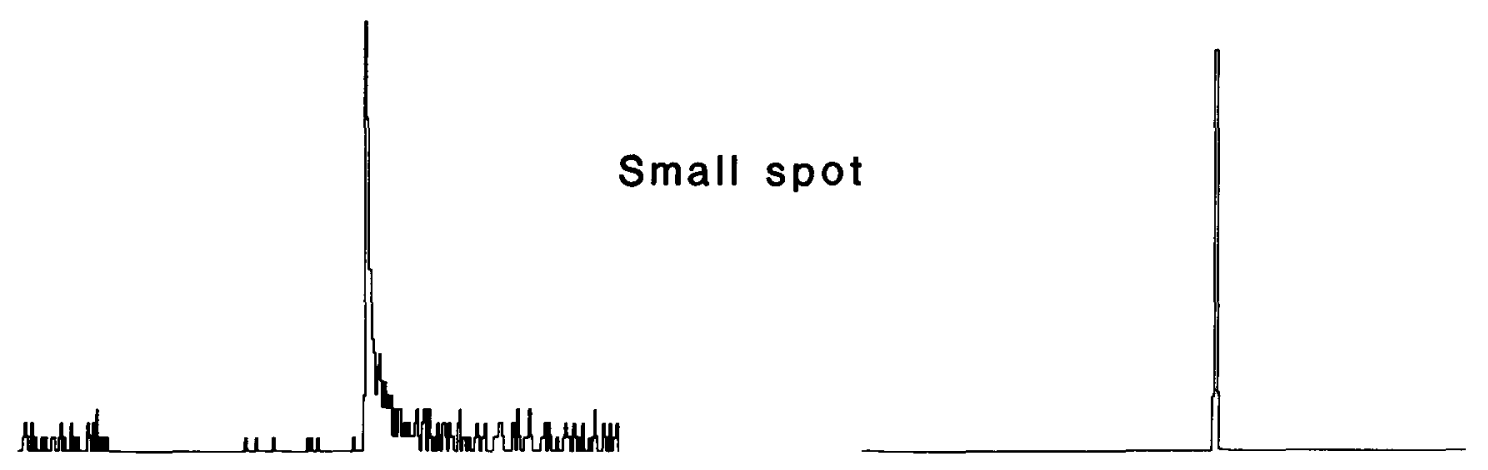

Large spot
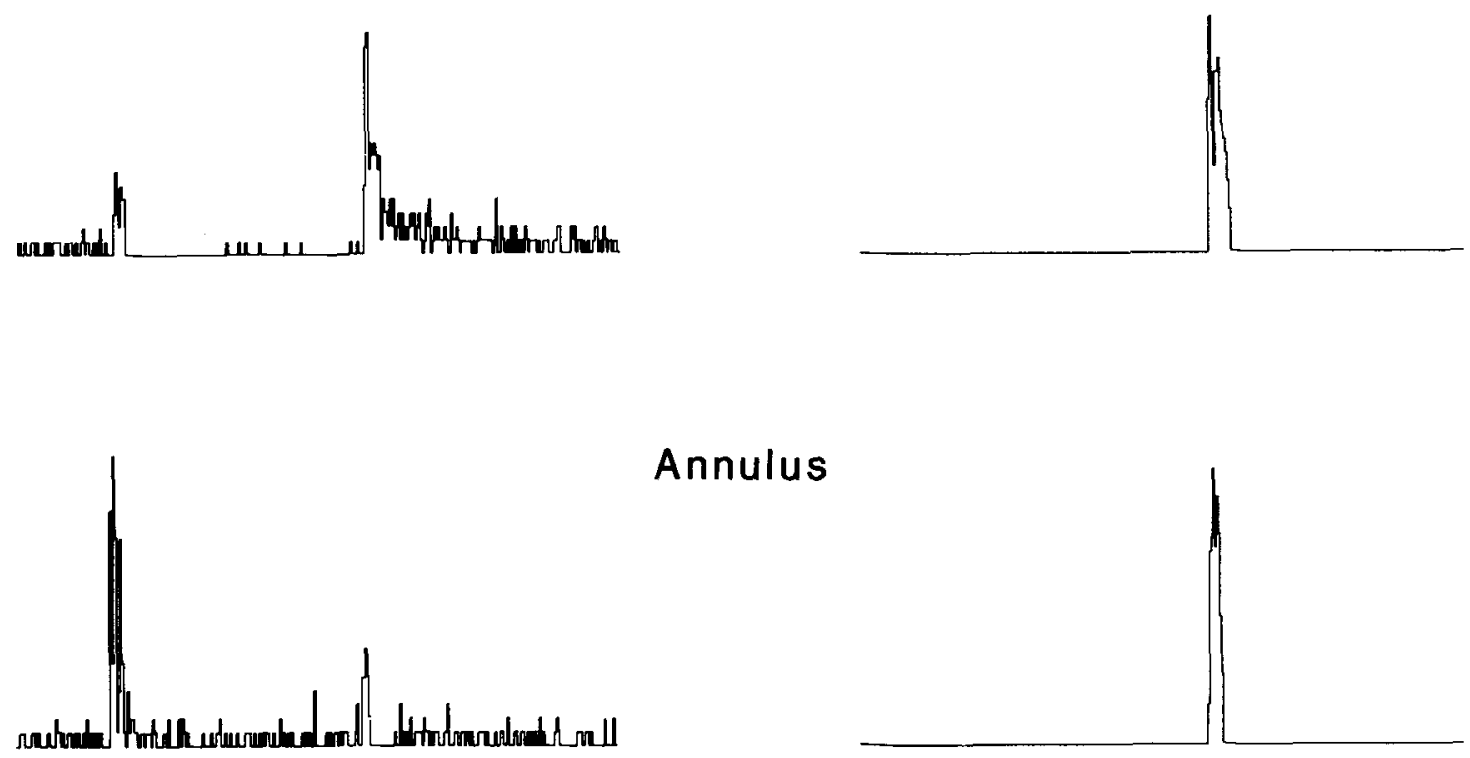

Annulus

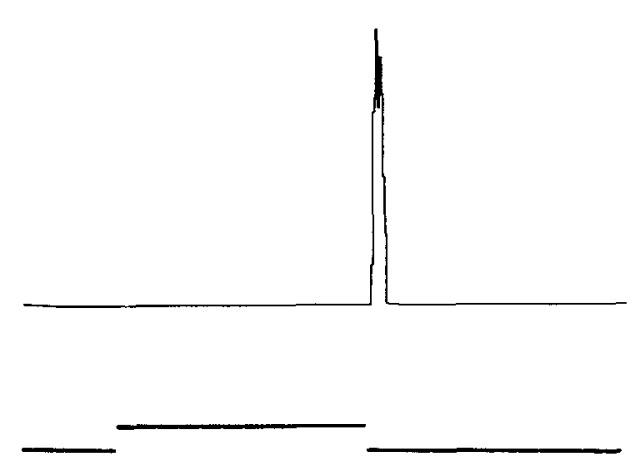

$100 / \sec$

$2 \mathrm{sec}$

Figure 2. Effect of haloperidol on an OFF-center brisk cell. Control and drug responses are to a small spot (1.0 degree $\left.{ }^{2}\right)$, a large spot (10 degrees $^{2}$ ), and an annulus (inner diameter, 2.7 degrees; outer diameter, 10 degrees) of light. Haloperidol abolished both the spontaneous activity and the antagonistic surround $\mathrm{ON}$ response. 


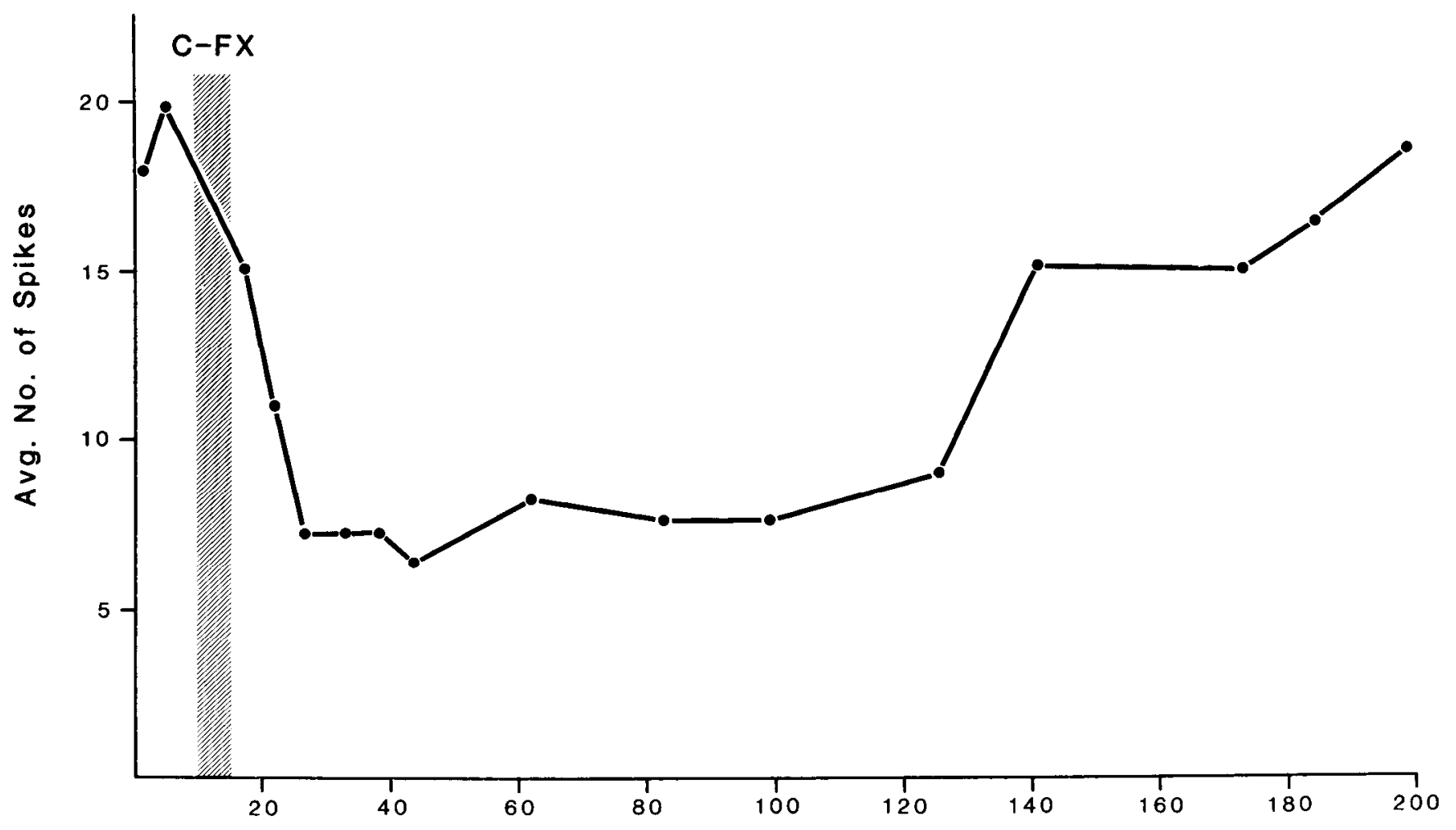

Time $(\min )$

Figure 3. Time course of the effect of cis-flupenthixol $(C-F X)$ on the surround ON response of an OFF-center brisk cell. The points plot the average number of spikes (for four repetitions) in response to an annulus (inner diameter, 6.7 degrecs; outcr diameter, 10 degrees) of light. The data show that the surround ON response decreased soon after the infusion of cis-flupenthixol, with the maximal effect occurring about 11 min thereafter. Recovery was essentially complete 185 min after infusion.

2.0 to $4.0 \%$. In later experiments the animals were anesthetized with an intraperitoneal injection of a urethane-chloralose mixture (urethane, $0.8 \mathrm{gm} / \mathrm{kg}$; chloralose, $80 \mathrm{mg} / \mathrm{kg}$ ). During surgery this was supplemented with 1.0 to $2.0 \%$ halothane in a $66 \%$ nitrous oxide, $34 \%$ oxygen mixture. We switched to the urethane-chloralose mixture as the anesthetic of choice when it was discovered in some preliminary experiments that $0.5 \%$ halothane elevated the dark-adapted absolute thresholds of ganglion cells considerably. The drug effects reported here, though, were similar under the two conditions.

The surgery and preparation of the animal were similar to those described previously (Caldwell and Daw, 1978; Ariel and Daw, 1982). Arteries of the right side of the neck were exposed. The lingual artery was ligated and a polythene cannula (for drug delivery) was inserted into the external maxillary artery with the tip near or in the external carotid artery. The animal was placed on a small platform with its head held in place with ear bars plus a chin bar, was paralyzed with an intramuscular injection of $d$-tubocurarine (initial and maintenance dose of $0.5 \mathrm{mg} / \mathrm{kg} / \mathrm{hr}$ ), and was artifically ventilated via a tracheal cannula. The respiration parameters were adjusted to maintain an expired $\mathrm{CO}_{2}$ of about $4.0 \%$, as measured with a Beckman gas analyzer. Body temperature, measured with a rectal thermometer, was kept at 37 to $38^{\circ} \mathrm{C}$ with a heating pad. The lids of the right eye were removed, three extraocular muscles were cut, and the conjunctiva was sewn to a ring near the limbus. A tungsten-in-glass microelectrode was advanced through a guard needle inserted into the vitreous and positioned with the aid of an ophthalmoscope in or near the visual streak. A contact lens was selected by retinoscopy to focus light stimuli projected on a tangent screen (138 cm from the eye) onto the retina.

Light stimuli were controlled by a MINC computer (Digital Equipment Corp.). The orientation (dove prism), the movement (penmotor), the size of the stimulus, and its timing (Ilex shutter) were all under computer control. The computer also collected spikes recorded by the electrode and stored them in peristimulus time histograms with a bin width of 20 or $50 \mathrm{msec}$. All histograms shown are the average of four repetitions of the stimulus. The experiments were performed at mesopic light levels with a background of, generally, $14 \mathrm{~cd} / \mathrm{m}^{2}$ (SEI photometer) and light stimulus of generally $86 \mathrm{~cd} / \mathrm{m}^{2}$.

With the exception of haloperidol, drugs were prepared just prior to use on the day of an experiment. Haloperidol (Janssen Pharmaceutica) was dissolved in a $0.4 \%$ lactic acid solution at $5 \mathrm{mg} / \mathrm{ml}$. Fluphenazine (E. R. Squibb \& Sons, Inc.), cis-flupenthixol (H. Lunbeck \& Co. A/S), and metoclopramide (Sigma Chemical Co.) were dissolved in saline at $10 \mathrm{mg} / \mathrm{ml}$. S-Sulpiride (Ravizza S.P.A.) was dissolved in saline (pH adjusted to 4.0 to 4.5 with citric acid) at $10 \mathrm{mg} / \mathrm{ml}$. Drugs were infused intra-arterially, usually at the same rate at which picrotoxin $(2 \mathrm{mg} / \mathrm{ml})$ abolished the directionality of a directionally selective cell (see Caldwell et al., 1978). This rate of infusion varied between 0.1 and $0.5 \mathrm{ml} / \mathrm{min}$ for each animal. At the lower rates of infusion, with a blood flow in the artery calculated to be $10 \mathrm{ml} / \mathrm{min}$, the drugs were diluted 100 -fold. With a 100 -fold dilution, the intra-arterial concentrations of the drugs would be 100 to $300 \mu \mathrm{M}$. The duration of drug infusions was from 3 to $5 \mathrm{~min}$.

\section{Results}

The following results were obtained from brisk ganglion cells and ON-OFF directionally selective ganglion cells. The effects on other ganglion cell types (i.e., W cells) are not described here since only a limited number of these cells have been sampled so far due to difficulty in holding these cells upon infusion of a dopamine antagonist. The $\mathrm{X} / \mathrm{Y}$ classification of brisk ganglion cells (commonly used in cat retinal studies) was not used here since the contrast reversing bipartite field used by Caldwell and Daw (1978) to determine whether a cell was $\mathrm{X}$-typc (gave a "null" response) or $\mathrm{Y}$-type (gave a "frequency doubling" response) did not correspond well with the sustained/ transient nature of a cell's response to a spot of light. For ONcenter brisk cells, the sustained/transient distinction was more appropriate in describing the effects of dopamine antagonists.

OFF-center brisk cells. The dopamine antagonists, haloperi- 


\section{Control}

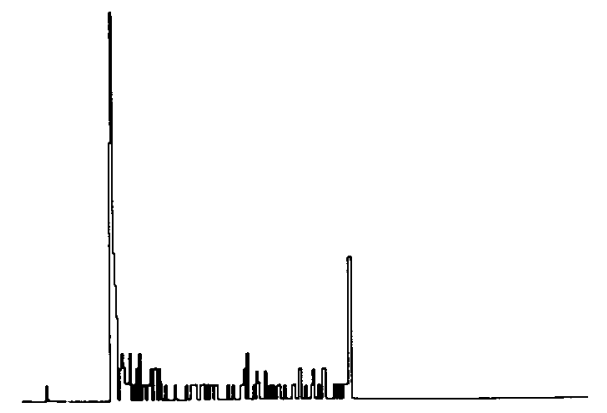

\section{Flupenthixol}

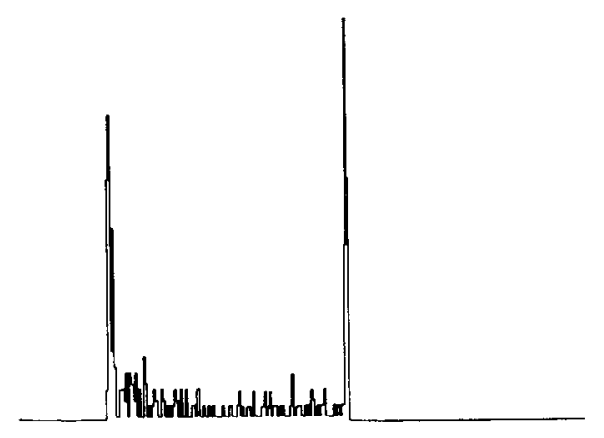

\section{Flupenthixol (2nd infusion)}
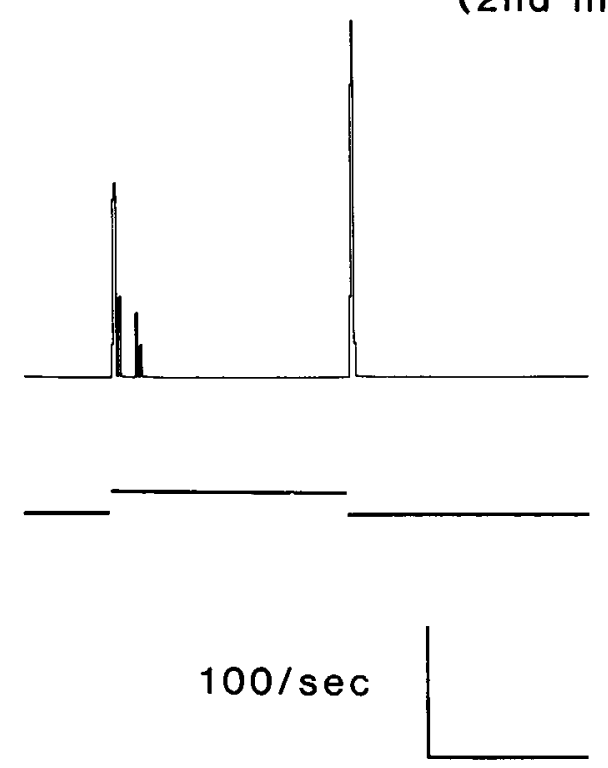

\section{2 sec}

Figure 4. Effect of cis-flupenthixol on the surround response of an OFF-center brisk cell. The middle histogram, taken 16 min after a 5min infusion of cis-flupenthixol, shows the reduction in the antagonistic influence of the surround. Sixty minutes after this initial infusion, at which time the cell showed very little signs of recovery, a second 5 -min infusion of cis-flupenthixol at the same concentration was given. This resulted in a further decrease of the antagonistic surround response (lower histogram). Stimulus was an annulus (inner diameter, 4.7 degrees; outer diameter, 10 degrees) of light. dol, fluphenazine, and cis-flupenthixol, reduced the antagonistic surround responses of $93 \%$ (25 of 27 ) of OFF-center brisk cells sampled. In addition, spontaneous activity of $80 \%$ (16 of 20) of OFF-center brisk cells examined was reduced. The effects of haloperidol on one OFF-center brisk cell are illustrated in Figure 1. Haloperidol reduced the spontaneous activity and the small sustained discharge upon illumination of the receptive field center. The OFF response to a small spot of light was also reduced. Of particular significance was the effect on the lightevoked response to an annulus of light. Haloperidol reduced the surround $O N$ response to the annulus of light and produced an OFF response to the same annular stimulus. The appearance or potentiation of an OFF response to an annulus of light was seen for $83 \%$ (15 of 18) of OFF-center brisk cells tested. On three occasions haloperidol abolished the surround $\mathrm{ON}$ response completely. This is illustrated for one cell in Figure 2. Here both the spontaneous activity and the $O N$ response to an annulus of light were eliminated after infusion of haloperidol. The OFF response to a large spot of light increased slightly, whereas the OFF response to an annulus of light increased dramatically. Note also that the OFF response to a small spot of light became more transient.

Under our experimental conditions, haloperidol was 2 to 3 times more potent than either cis-flupenthixol or fluphenazine. This is interesting since experiments utilizing intact carp retinal pieces (Dowling and Watling, 1981) show haloperidol to be more effective in antagonizing dopamine-induced cAMP production than either fluphenazine or cis-flupenthixol. In homogenates of carp retina, fluphenazine and cis-flupenthixol are more potent than haloperidol (Watling and Dowling, 1981).

Although the effects of dopamine antagonists began during infusion or shortly afterwards, the maximal effects usually occurred 5 to $15 \mathrm{~min}$ after the end of infusion (see Fig. 3). Recovery from the effects of the dopamine antagonists took 1 to $3 \mathrm{hr}$, sometimes longer. The GABA antagonist picrotoxin, in contrast, when infused into the blood supply under similar conditions, exhibited its maximal effects during infusion or 1 to 2 min afterwards, with the effects being virtually absent about 20 min later (Caldwell et al., 1978; R. Jensen and N. Daw, unpublished observations).

In a few cases, before a cell had recovered from an infusion of a dopamine antagonist, a second infusion was done. In all cases the second infusion potentiated the effects of the first infusion. Figure 4 illustrates the effect of cis-flupenthixol on an annular (surround) response of an OFF-center brisk cell following two separate infusions of the antagonist. The first infusion of cis-flupenthixol reduced the transient $O N$ response and accentuated the OFF response to the annulus of light. Before the cell had recovered, cis-flupenthixol was infused a second time. Both the transient and sustained components of the surround $O N$ response were reduced, while the OFF response remained essentially unchanged. The results from this and other cells show that the effects of dopamine antagonists were dose dependent.

A distinct subclass of brisk ganglion cell are the fast movement-selective large field units (Vaney et al., 1981) as originally described by Barlow et al. (1964). Fifteen of the 27 OFF-center brisk cells sampled were large field units. The effects of dopamine antagonists on these cells were similar to the effects observed for other OFF-center brisk cells; spontaneous activity decreased and the center-surround balance shifted in favor of the center (see Fig. 5). Note in Figure 5 that, with an annulus of light, an OFF response now appears along with the transient ON response. Unlike other OFF-center brisk cells, large field units gave vigorous $\mathrm{ON}-\mathrm{OFF}$ responses to large spots of light. As illustrated for the cell in Figure 5, the surround $O N$ response to a large spot of light was abolished after infusion of haloperidol. This lack of an ON response to a large spot of light after 
Control

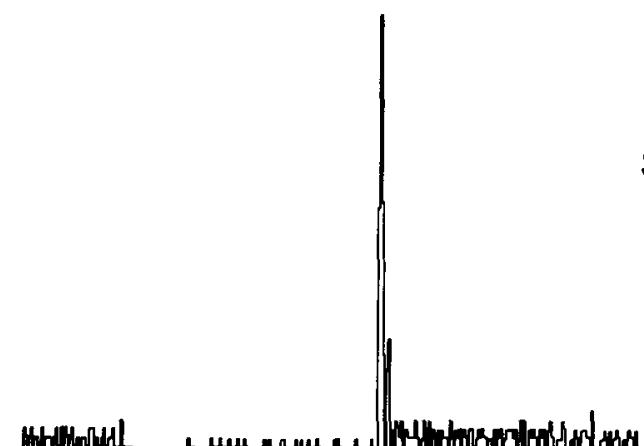

Haloperidol

\section{Small spot}

Large spot
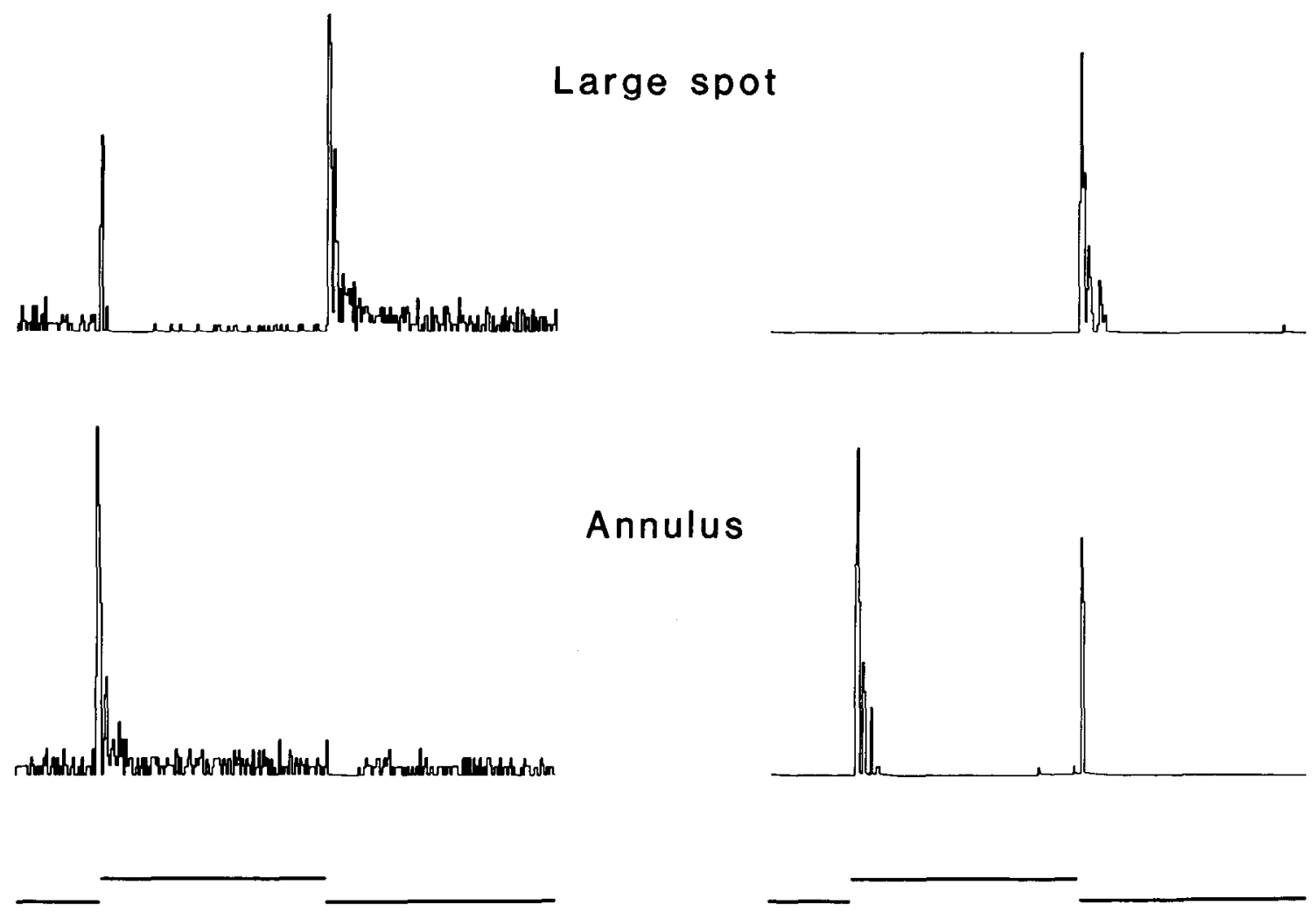

$2 \mathrm{sec}$

Figure 5. Effect of haloperidol on an OFF-center large field unit. Control and drug responses are to a suall spot (2.0 degrees $\left.{ }^{2}\right)$, a large spot (18 degrees $^{2}$ ), and an annulus (inner diameter, 12 degrees; outer diameter, 18 degrees) of light. Haloperidol abolished the spontaneous activity and altered the center-surround balance in favor of the center. 


\section{Control}

\section{Haloperidol}

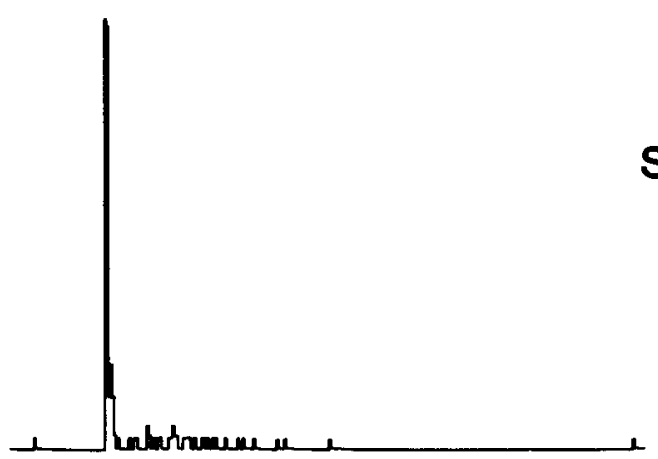

Small spot

Large spot
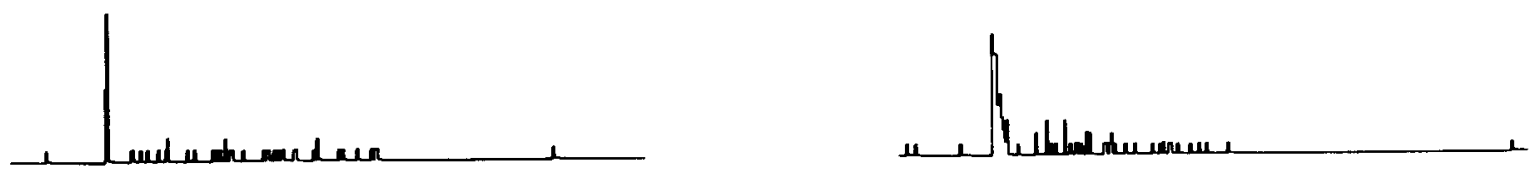

\section{Annulus}
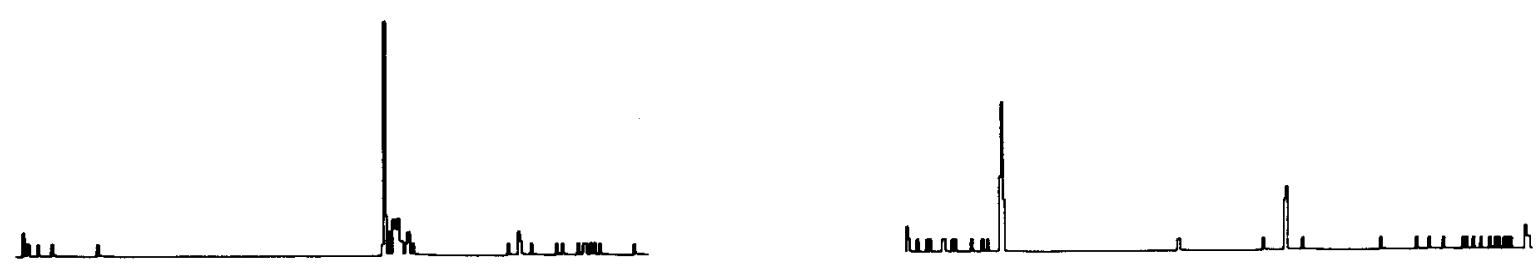

$100 / \mathrm{sec}$

$2 \mathrm{sec}$

Figure 6. Effect of haloperidol on an ON-center brisk-transient cell. Control and drug responses are to a small spot (1.0 degree ${ }^{2}$, a large spot (10 degrees ${ }^{2}$ ), and an annulus (inner diameter, 2.7 degrees; outer diameter, 10 degrees) of light. Haloperidol altered the center-surround balance in favor of the center and increased the spontaneous activity from $1.3 \mathrm{spikes} / \mathrm{sec}$ to $3.0 \mathrm{spikes} / \mathrm{sec}$. 


\section{Control}

Haloperidol

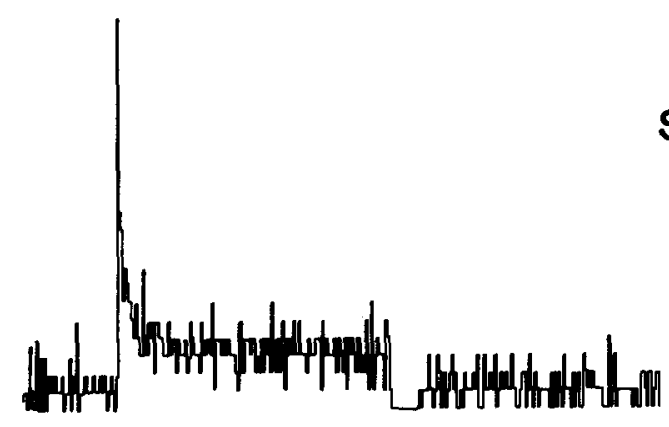

Small spot

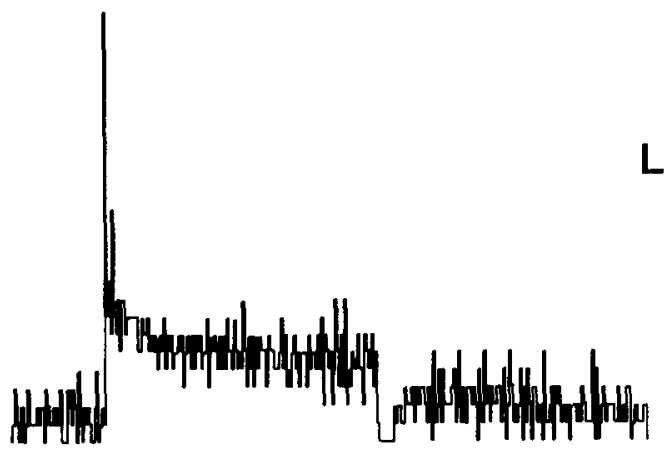

Large spo
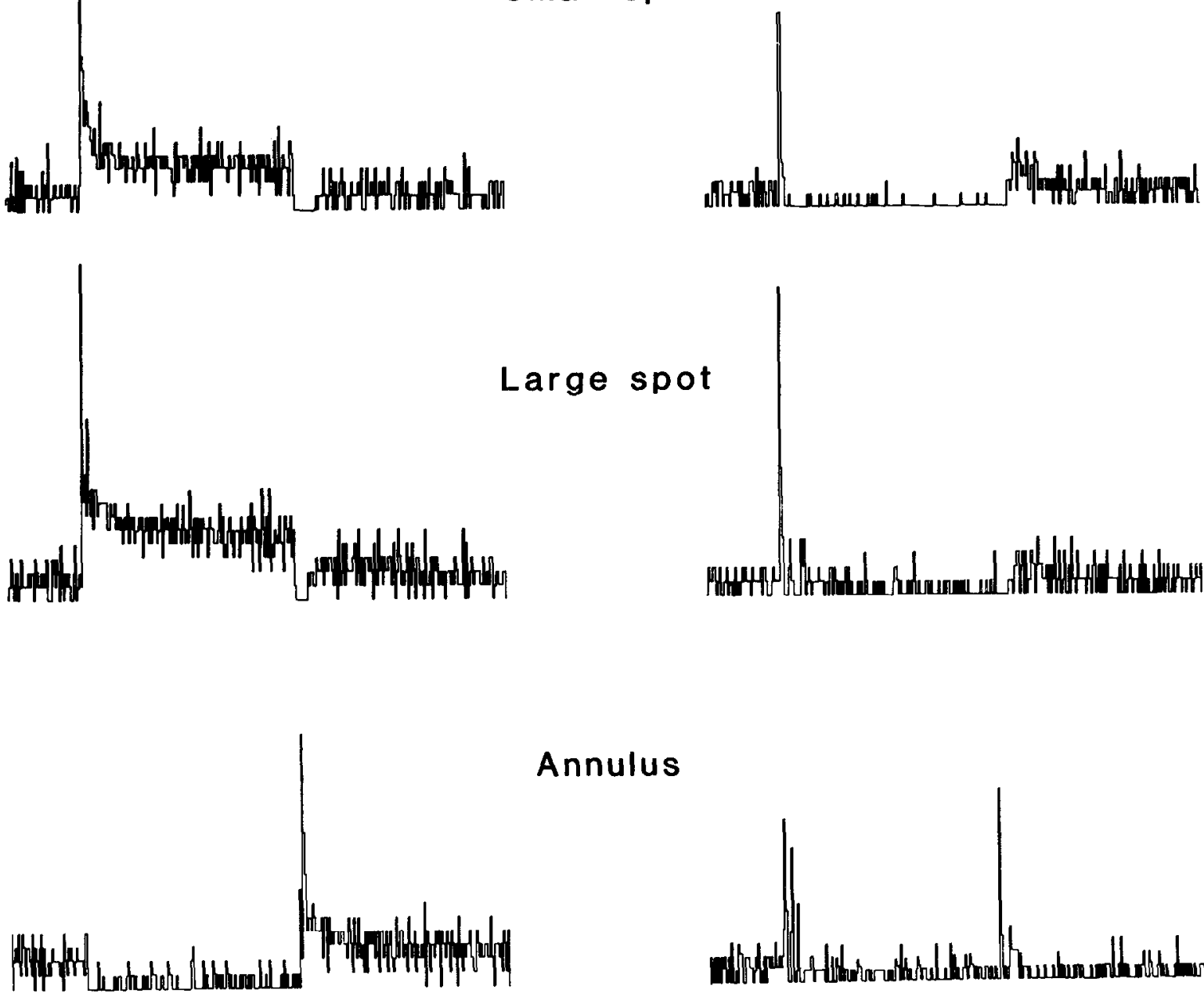

Annulus
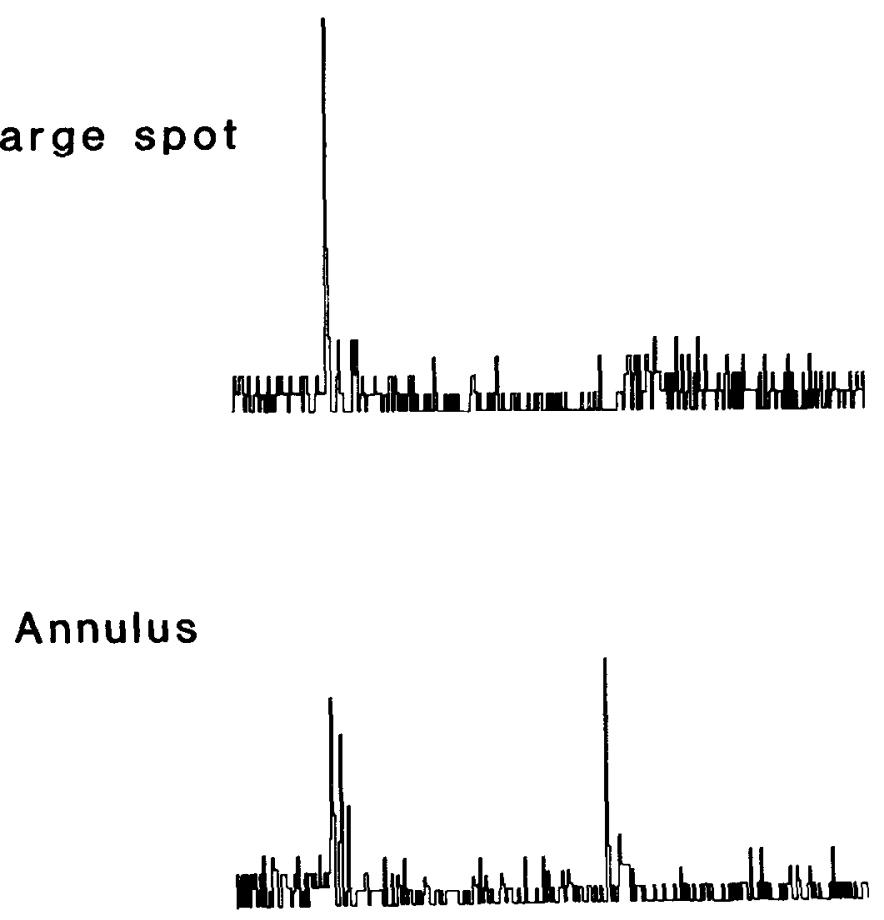

$100 / \mathrm{sec}$

$2 \mathrm{sec}$

Figure 7. Effect of haloperidol on an $\mathrm{ON}$-center brisk-sustained cell. Control and drug responses are to a small spot (2.0 degrees ${ }^{2}$ ), a large spot (16 degrees ${ }^{2}$ ), and an annulus (inner diameter, 6.7 degrees; outer diameter, 16 degrees) of light. Haloperidol produced a sustained inhibition to the spots of light and an ON response to the annulus of light. Although the records give the impression that spontaneous activity decreased with haloperidol, the spontaneous activity at the time the drug records were taken was essentially the same as in the control records. 


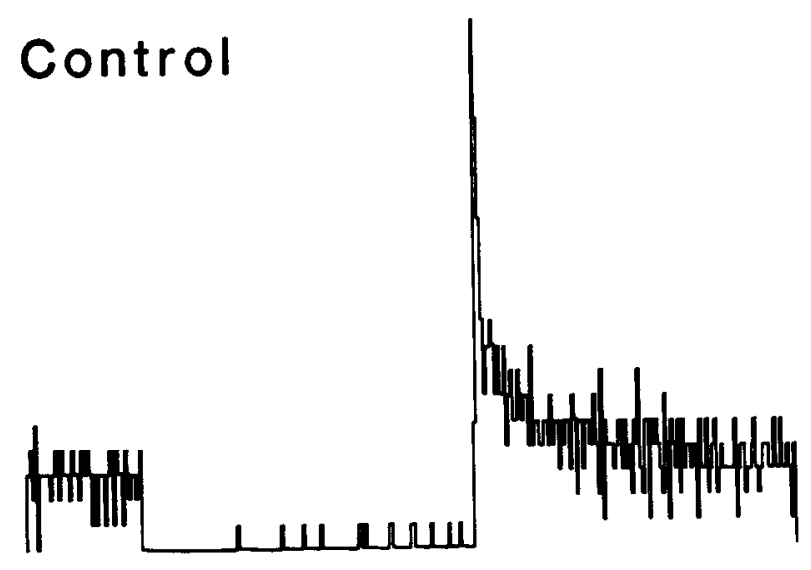

\section{Haloperidol}

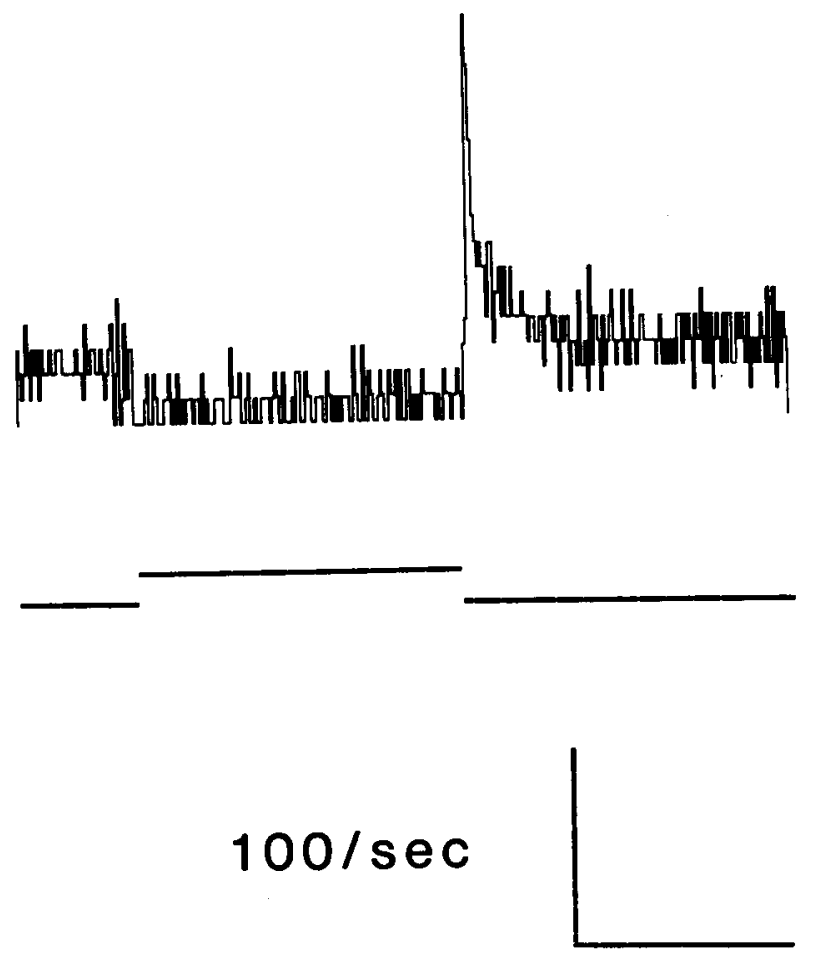

\section{$2 \mathrm{sec}$}

Figure 8. Effect of haloperidol on the surround OFF response of an ON-center brisk-sustained cell. Haloperidol decreased the sustained inhibition to an annulus (inner diameter, 3.7 degrees; outer diameter, 16 degrees) of light. This effect occurred with no change in the spontaneous activity of the cell.

infusion of a dopamine antagonist was observed for 73\% (11 of 15) OFF-center large field units. Only one of these cells showed no decrease in its ON response to a large spot of light.

Along with changes in the amplitudes of light-evoked responses almost all OFF-center brisk cells showed increased response latencies after treatment with a dopamine antagonist. The surround $\mathrm{ON}$ responses of $\mathrm{OFF}$-center large field units
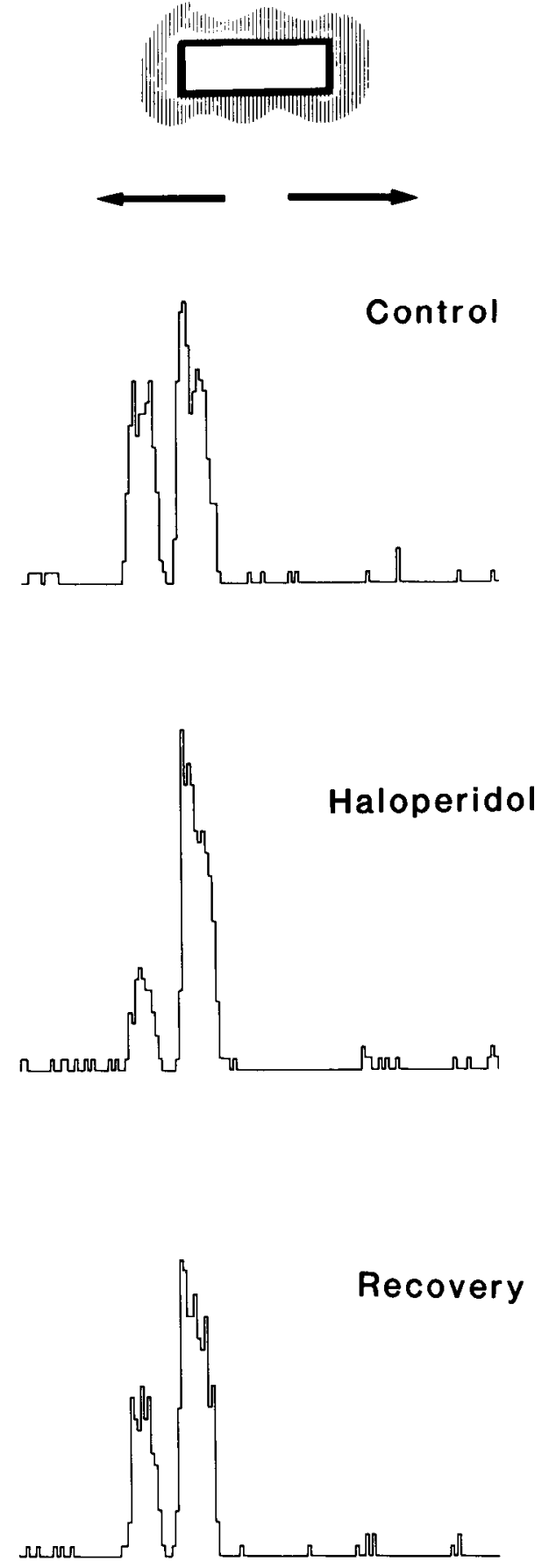

LE TE

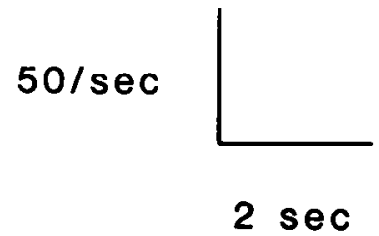

Figure 9. Effect of haloperidol on an ON-OFF directionally selective cell to a moving light stimulus. Haloperidol reduced the leading edge $(L E)$ response to a bar (1.0 degree $\times 3.0$ degrees) of light moved in the preferred direction (5.0 degrees/sec) while not having much effect on the trailing edge (TE) response. Recovery record was taken $98 \mathrm{~min}$ after drug infusion. 
TABLE I

Proportion of cells affected by dopamine antagonists Spontaneous Activity Shift in CenterSurround

Increase No change Decrease Balance in Favor of the Center ${ }^{a}$

\begin{tabular}{lllcc} 
OFF cells & $0 / 20$ & $4 / 20$ & $16 / 20$ & $25 / 27$ \\
ON-transient cells & $5 / 6$ & $1 / 6$ & $3 / 6^{b}$ & $7 / 8$ \\
ON-sustained cells & $4 / 6$ & $1 / 6$ & $2 / 6^{b}$ & $4 / 5$ \\
\hline
\end{tabular}

${ }^{a}$ For most cells a shift in center-surround balance was determined with an annulus of light; this was especially true for $\mathrm{ON}$-sustained cells.

${ }^{b}$ Included are cells in which spontaneous activity decreased below control value after having initially increased.

were delayed up to $60 \mathrm{msec}$ ( 3 bins). No detectable change was observed in the latencies of their OFF responses; however, changes in latencies less than 20 msec could not be detected by our system. For other OFF-center cells, OFF responses in addition to $\mathrm{ON}$ responses were frequently delayed. Delays of 40 to $60 \mathrm{msec}$ ( 2 to $3 \mathrm{bins}$ ) in either the OFF or ON responses were common. These increases in response latencies are interesting since delayed visual evoked potentials have been observed in schizophrenic patients upon treatment with neuroleptic drugs (dopamine antagonists) (Bodis-Wollner et al., 1982).

ON-center brisk cells. ON-center brisk cells could be divided into two classes, ON-sustained cells and ON-transient cells, according to their responses to small spots of light centered on their receptive fields.

Seven of eight ON-center brisk-transient cells showed a shift in their center-surround balance in favor of the center, much like OFF-center brisk cells, after infusion of haloperidol or fluphenazine. The effects of haloperidol on one ON-center brisk-transient cell are illustrated in Figure 6. This cell, which gave only a surround OFF response to an annulus of light, gave an $\mathrm{ON}-\mathrm{OFF}$ response after infusion of haloperidol. The surround OFF response was markedly attenuated in addition to being delayed $160 \mathrm{msec}$. Delays of at least 80 to $100 \mathrm{msec}$ in the surround OFF responses of ON-center brisk-transient cells were common. No delays in the $\mathrm{ON}$ responses of these cells were noted. As illustrated for the cell in Figure 6, the center $\mathrm{ON}$ responses of $\mathrm{ON}$-center brisk-transient cells to spots of light were frequently prolonged, i.e., less transient. Spontaneous activity of $\mathrm{ON}$-center brisk-transient cells, unlike OFFcenter brisk cells, in general increased after infusion of a dopamine antagonist. It was not uncommon, however, to see the spontaneous activity return to, or below, control value while the effects on the light-evoked responses remained essentially unchanged.

ON-center brisk-sustained cells $(N=6)$ showed, following infusion of haloperidol, a reduction in their sustained ON activity to spots of light. For three ON-center brisk-sustained cells the sustained excitation to spots of light actually turned into sustained inhibition (see Fig. 7). It appears that this sustained inhibition was originating within the center of the receptive field. Small spots of light were more effective in inhibiting the cells than were large spots of light. Furthermore, stimulation of the receptive field surround of the three $\mathrm{ON}$ center brisk-sustained cells with an annulus of light did not increase the sustained inhibition. In fact, there appeared to be less inhibition with an annulus of light (see Figs. 7 and 8). For the cell illustrated in Figure 7, an annulus of light produced an ON response where there was not one previously. It appears, therefore, that the antagonistic surrounds of these cells were reduced. The surround OFF responses of the ON-center brisksustained cells, in contrast to ON-center brisk-transient cells, were not markedly delayed. For one-half ( 3 of 6 ) of the cells the OFF responses were delayed only about $20 \mathrm{msec}(1 \mathrm{bin})$.
No delay in the $\mathrm{ON}$ responses was detected. The effect of haloperidol on the spontaneous activity of ON-center brisksustained cells was to increase it (at least initially). The spontaneous activity (measured from a $30-\mathrm{sec}$ interval) for the cell in Figure 7 increased from 14.7 spikes/sec to 23.8 spikes/sec after infusion of haloperidol and then slowly decreased to 14.5 spikes/sec at the time the drug records were taken 75 min later.

Although dopamine antagonists had a differential effect on the spontaneous activity of OFF- and ON-center brisk cells, they had a common effect in reducing the antagonistic surround influence of these cells (see Table I).

ON-OFF directionally selective cells. The effect of haloperidol on ON-OFF directionally selective cells $(N=8)$ to a moving light stimulus was to reduce the leading edge response while either not affecting or increasing slightly the trailing edge response (see Fig. 9). The leading edge response was abolished completely for two directionally selective cells (not shown). The retention of directional selectivity of these cells suggests that the underlying mechanism does not depend upon an interaction between the ON and OFF pathways to these cells.

One-half (4 of 8 ) of the directionally selective cells gave a small sustained excitation to a small spot of light centered on their receptive fields. The effect of haloperidol on these cells was similar to that observed for ON-center brisk-sustained cells. Haloperidol converted any sustained excitation to sustained inhibition while sparing the transient $\mathrm{ON}$ component of the response (Fig. 10). The transient ON response for the cell of Figure 10 actually increased for both small and large spots of light. The spontaneous activity of directionally selective cells was not affected much, and only two of the eight cells showed any delay in their response latencies to spots of light. For these two cells the OFF responses were delayed approximately 20 msec (1 bin).

Effects of $D-2$ antagonists. In addition to dopamine receptors linked to adenylate cyclase (D-1 receptors), D-2 receptors (not linked to adenylate cyclase) are present in the rabbit retina where they are postulated to function as presynaptic autoreceptors (Dubocovich and Weiner, 1981). The substituted benzamides metoclopramide and $S$-sulpiride are reported to act selectively at D-2 receptors (Kebabian and Calne, 1979). $S$ Sulpiride has been shown in the rabbit retina to be 10 times more potent than fluphenazine and at least 1000 times more potent than cis-flupenthixol at the $\mathrm{D}-2$ receptors (Dubocovich and Weiner, 1981). At the D-1 receptors in the rabbit retina, sulpiride $(100 \mu \mathrm{M})$ has been shown to have no antagonistic activity (Magistretti and Schorderet, 1978). We found that metoclopramide had no significant effect on the activity of three recorded cells (OFF-center large field unit and two ONOFF directionally selective cells), whereas $S$-sulpiride did reduce the spontaneous activity of two OFF-center brisk cells. For one of these cells the light-evoked responses were also reduced (Fig. 11). For two other cells (OFF-center large field unit and $O N$-center brisk-sustained cell), $S$-sulpiride had no apparent effect. The inability of either $S$-sulpiride or metoclopramide to alter the light-evoked responses of ganglion cells in a manner similar to those of the other dopamine antagonists suggests that the drug effects we have observed in this study are due to a blockade of D-1 receptors rather than D-2 receptors.

\section{Discussion}

In the rabbit, dopamine is confined to a class of amacrine cell which makes contact only with other amacrine cells in the IPL (Dowling and Ehinger, 1978b; Holmgren-Taylor 1982). Therefore, the drug effects reported here are presumably mediated via amacrine cells which in turn directly or indirectly influence ganglion cell activity. In the rabbit retina (Bauer et al., 1980), as well as in other vertebrate retinas (Kramer, 1971; 


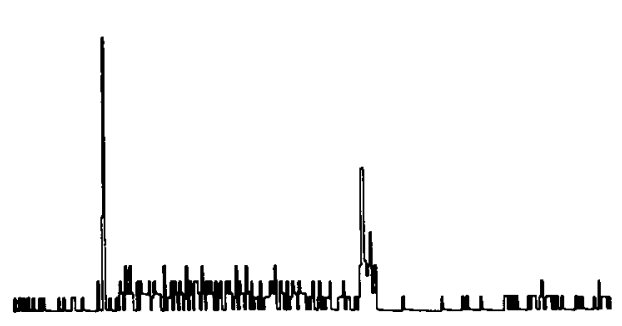

\section{Control}

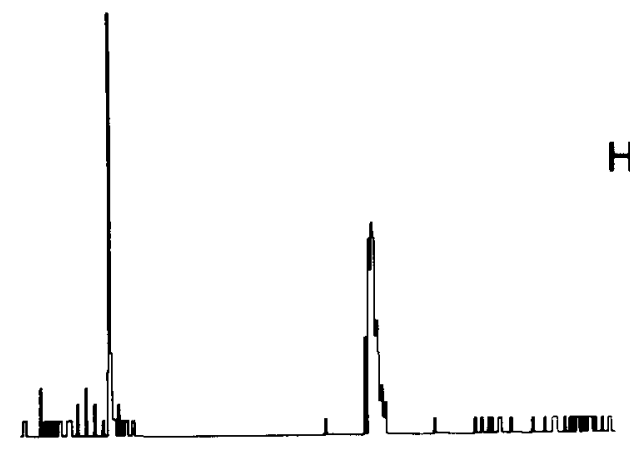

\section{Haloperidol}
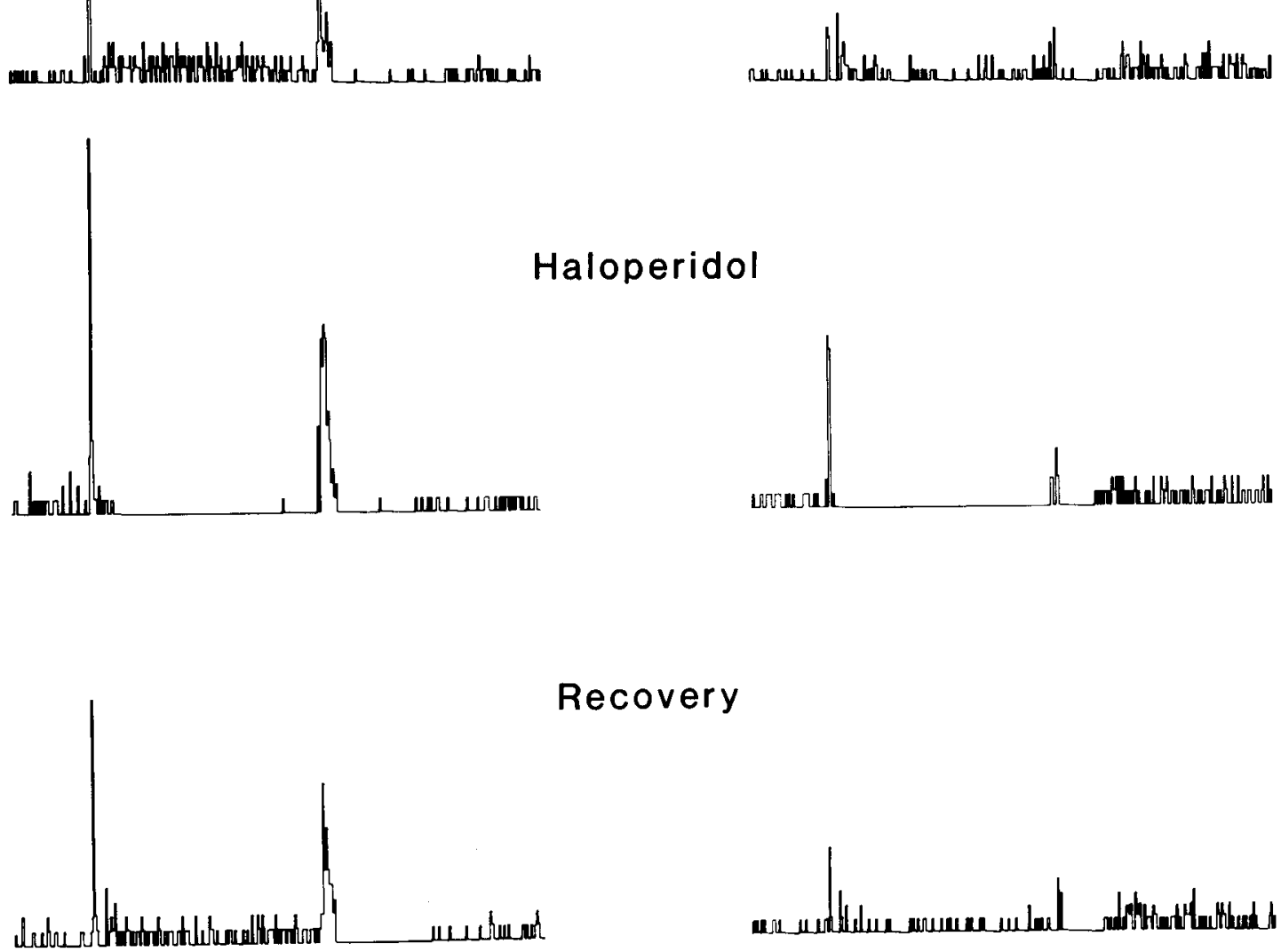

Recovery

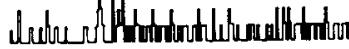
11.uluent

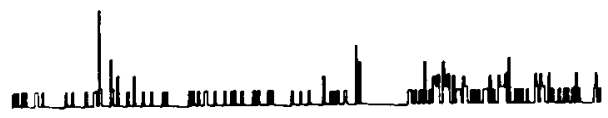

$100 / \mathrm{sec}$

Figure 10. Effect of haloperidol on an ON-OFF directionally selective cell to stationary spot stimuli. Control and drug responses are to a small spot (2.0 degrees $\left.{ }^{2}\right)$ and a large spot $\left(10\right.$ degrees $\left.^{2}\right)$ of light. Halperidol produced a sustained inhibition to the spots of light while increasing the ON-transient component. Recovery records were taken about $95 \mathrm{~min}$ after drug infusion. This cell is the same cell illustrated in Figure 9. 
Control

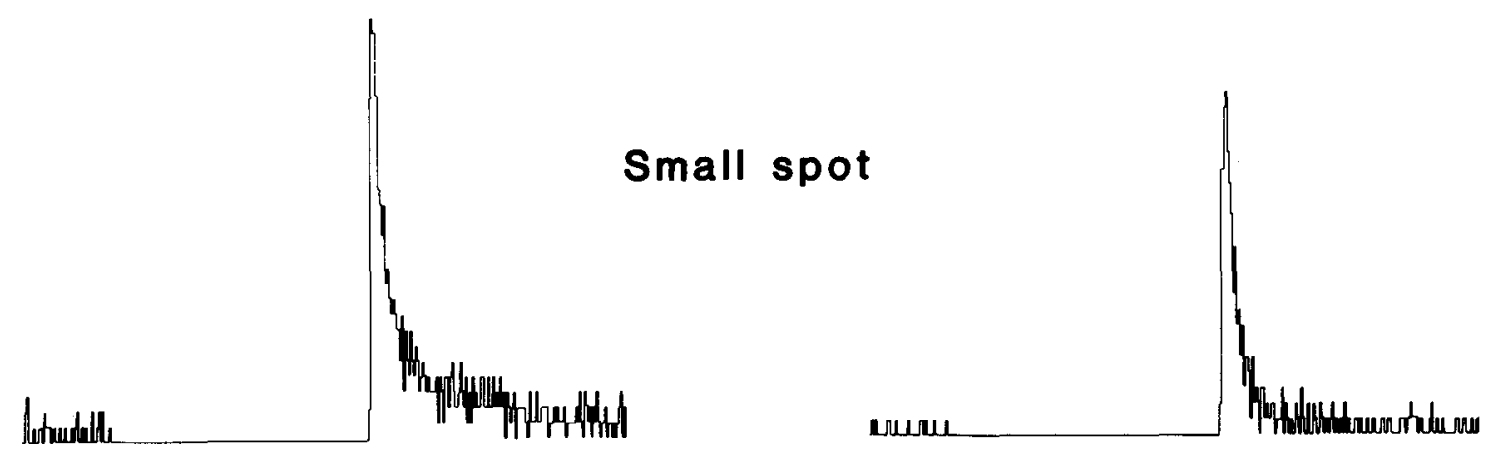

Sulpiride

\section{Large spot}
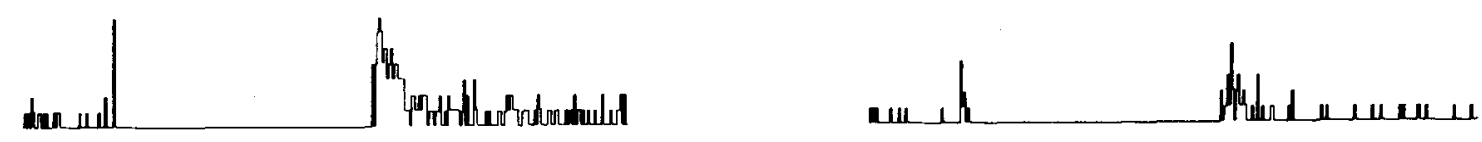

Annulus

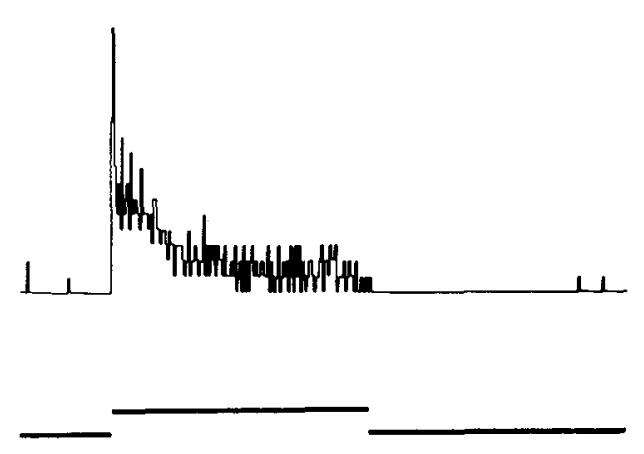

$100 / \sec$

Figure 11. Effect of $S$-sulpiride on an OFF-center brisk cell. Control and drug responses are to a small spot (2.0 degrees $\left.{ }^{2}\right)$, a large spot (18 degrees ${ }^{2}$ ), and an annulus (inner diameter, 4.7 degrees; outer diameter, 18 degrees) of light. $S$-Sulpiride decreased both spontaneous activity and light-evoked responses. Note that there is no indication of a shift in center-surround balance. 
Dowling and Watling, 1981; Reading, 1983), dopamine is released by light stimulation. The finding in our experiments that spontaneous activity of ganglion cells could be affected by dopamine antagonists suggests that there is a continuous dopamine release in the light-adapted rabbit retina. Whereas OFF-center brisk ganglion cells showed a decrease in spontaneous activity after infusion of a dopamine antagonist, ONcenter brisk ganglion cells, in general, showed an increase in spontaneous activity. This differential effect on spontaneous activity of OFF- and $\mathrm{ON}$-center brisk ganglion cells is presumably a reflection of the indirect site of action of the dopamine antagonists.

A common effect of dopamine antagonists on the centersurround organization of brisk ganglion cells was the reduction in the antagonistic surrounds (see Table I). The fact that the antagonistic surround responses could be markedly reduced and even abolished with dopamine antagonists suggests that the center-surround balance of these cells is under tight dopaminergic regulation. In the cat retina, the center-surround organization of ganglion cells undergoes a change with light/ dark adaptation such that the discharge from the receptive field surround diminishes considerably with dark adaptation (Barlow et al., 1957; Enroth-Cugell and Lennie, 1975; Barlow and Levick, 1976). This phenomenon appears not to be associated with the transition from cone to rod function but occurs through some other mechanism (Barlow et al., 1957). The dramatic effects we have found of dopamine antagonists on the surround responses of brisk ganglion cells in the light-adapted state combined with the evidence that dopaminergic neurons are less active in the dark (DaPrada, 1977; Iuvone et al., 1978; Proll and Morgan, 1982; Parkinson and Rando, 1983) suggest that the neurotransmitter dopamine may play an important role in this change in center-surround organization with dark adaptation. Anatomically, dopaminergic neurons in the retina have very large dendritic fields (Ehinger, 1983; Brecha et al., 1984), making them well suited for such a role which might require integrating signals over a vast area.

The dramatic effect of dopamine antagonists on the sustained $\mathrm{ON}$ responses of $\mathrm{ON}$-center brisk-sustained cells and $\mathrm{ON}-\mathrm{OFF}$ directionally selective cells was surprising. The sustained excitation upon illumination of the receptive field centers decreased and, in many cases, converted to sustained inhibition. This finding is difficult, at present, to relate to any possible functional role of dopamine in the retina. However, a possible anatomical pathway mediating such an effect may be worth comment. In the cat retina, as in the rabbit retina, dopaminergic neurons stratify primarily in the outer portion of the IPL (Ehinger, 1983), where OFF-center ganglion cells but not ONcenter ganglion cells send their dendritic processes (Famiglietti and Kolb, 1976; Nelson et al., 1978; Bloomfield and Miller, 1981; Amthor et al., 1982). A pathway interconnecting dopaminergic amacrine cells with the receptive field centers of $\mathrm{ON}$ center ganglion cells has been described in the cat retina. Pourcho (1982) demonstrated anatomically that dopaminergic amacrine cells of the cat retina provide extensive synaptic input to type AII amacrine cells. 'I'hese latter amacrine cells, which receive predominantly rod input, form large gap junctions with a particular class of depolarizing cone bipolar cell in the inner portion of the IPL (Nelson and Kolb, 1983). It is believed that these cone bipolar cells provide a major, excitatory input to ON-center brisk-sustained (X-type) ganglion cells (Sterling, 1983). Theoretically, dopamine antagonists acting via AII amacrine cells could alter the center, sustained excitatory input to ON-center brisk-sustained ganglion cells (and presumably also to ON-OFF directionally selective cells). At present, whatever the mechanism underlying the decrease in sustained excitation upon illumination of the receptive field centers of $\mathrm{ON}$-center brisk-sustained cells and ON-OFF directionally selective cells in the rabbit retina, these two cell types appear to share an $\mathrm{ON}$ pathway within the IPL.

Thier and Alder (1984) have recently reported that both the center and surround responses of ganglion cells decrease upon application of dopamine to the cat retina. Preliminary data obtained by us from recordings of OFF-center brisk ganglion cells in the isolated, perfused rabbit eyecup preparation suggest that exogenous dopamine decreases both the center and surround responses there also (unpublished observations). However, Thier and Alder (1984) suggest that the surround mechanism is more heavily affected by dopamine than is the center and concluded that dopamine causes a shift in the centersurround balance of ganglion cells in favor of the center. This finding appears to be in contradiction with our results on the effects of dopamine antagonists on rabbit ganglion cells. We believe that this difference between their results and ours is probably due to methodological rather than species differences. First, they used iontophoresis, whereas we perfused the entire retina, and the effects of iontophoretically applied drugs are believed to decrease with distance from the tip of the electrode. Second, the effects of dopamine applied to the retina are not necessarily predicted from the effects of dopamine antagonists. Exogenously applied dopamine may not mimic the actions of endogenous dopamine release, which is likely to be temporally and spatially modulated by light stimuli. To evaluate the functional role of dopamine released in the retina in response to light stimuli, we believe that (1) one should use a dopamine antagonist rather than dopamine itself, and (2) one should apply the antagonist so that it reaches all parts of the receptive field uniformly. We suggest, therefore, that the best evidence is that naturally released dopamine in the light-adapted retina acts to maintain the antagonistic surround responses of ganglion cells.

A real species difference between cat and rabbit may exist with respect to the effect of dopamine on the spontaneous activity of OFF-center ganglion cells. Thier and Alder (1984) found, as did Straschill and Perwein (1975), that dopamine decreases the spontaneous activity of OFF-center ganglion cells whereas, from recordings from OFF-center ganglion cells in the rabbit retina in vitro, Ames and Pollen (1969) and we (unpublished observations) have found that dopamine increases spontaneous activity.

In summary, the results from our studies on the effects of dopamine antagonists on ganglion cell recordings suggest that dopaminergic neurons within the retina play a prominent role in the formation of the center-surround organization of ganglion cells and, possibly, in the control of the state of adaptation of ganglion cells in the retina.

\section{References}

Ames, A., III, and D. A. Pollen (1969) Neurotransmission in central nervous tissue: A study of isolated rabbit retina. I. Neurophysiol. 32: 424-442.

Amthor, F. R., C. W. Oyster, and E. S. Takahashi (1982) Structure/ function correlations of rabbit retinal ganglion cells. Invest. Ophthal mol. Vis. Sci. Suppl. 22: 279.

Ariel, M., and N. W. Daw (1982) Effects of cholinergic drugs on receptive field properties of rabbit retinal ganglion cells. J. Physiol (Lond.) 324: 135-160.

Barlow, H. B., and W. R. Levick (1976) Threshold setting by the surround of cat retinal ganglion cells. J. Physiol. (Lond.) 259: 737757

Barlow, H. B., R. Fitzhugh, and S. W. Kuffler (1957) Change of organization in the receptive fields of the cat's retina during dark adaptation. J. Physiol. (Lond.) 137: 338-354.

Barlow, H. B., R. M. Hill, and W. R. Levick (1964) Retinal ganglion cells responding selectively to direction and speed of image motion in the rabbit. J. Physiol. (Lond.) 173: 377-407.

Bauer, B., B. Ehinger, and L. Aberg (1980) 3H-Dopamine release from 
the rabbit retina. Ablrecht von Graefes Arch. Klin. Exp. Ophthalmol. 215: $71-78$.

Bloomfield, S. A., and R. F. Miller (1981) Functional stratification of on and off pathways in the rabbit retina. Invest. Ophthalmol. Vis. Sci. Suppl. 20: 13.

Bodis-Wollner, I., M. D. Yahr, L. Mylin, and J. Thornton (1982) Dopaminergic deficiency and delayed visual evoked potentials in humans. Ann. Neurol: 1 1: 478-483.

Brecha, N. C., C. W. Oyster, and E. S. Takahashi (1984) Identification and characterization of tyrosine hydroxylase immunoreactive amacrine cells. Invest. Ophthalmol. Vis. Sci. 25: 66-70.

Brown, J. H., and M. H. Makman (1973) Influence of neuroleptic drugs and apomorphine on dopamine-sensitive adenylate cyclase of retina. J. Neurochem. 21: 477-479.

Bucher, M. -B., and M. Schorderet (1975) Dopamine- and apomorphine-sensitive adenylate cyclase in homogenates of rabbit retina. Naunyn-Schmiedebergs Arch. Pharmacol. 288: 103-107.

Caldwell, J. H., and N. W. Daw (1978) New properties of rabbit retinal ganglion cells. J. Physiol. (Iond.) 276: 257-276.

Caldwell, J. H., N. W. Daw, and H. J. Wyatt (1978) Effects of picrotoxin and strychnine on rabbit retinal ganglion cells: Lateral interactions for cells with more complex receptive fields. J. Physiol. (Lond.) 276: $277-298$.

DaPrada, M. (1977) Dopamine content and synthesis in retina and $\mathrm{n}$. accumbens septi: Pharmacological and light-induced modifications. Adv. Biochem. Psychoparmacol. 16: 311-319.

Dowling, J. E., and B. Ehinger (1978a) The interplexiform cell system. I. Synapses of the dopaminergic neurons of the goldfish retina. Proc. R. Soc. Lond. Biol, 201: 7-26.

Dowling, J. E., and B. Ehinger (1978b) Synaptic organization of the dopaminergic neurons in the rabbit retina. J. Comp. Neurol. 180: $203-220$.

Dowling, J. E., and K. J. Watling (1981) Dopaminergic mechanisms in the teleost retina. II. Factors affecting the accumulation of cyclic AMP in pieces of intact carp retina. J. Neurochem. 36: 569-579.

Dowling, J. E., B. Ehinger, and I. Floren (1980) Fluorescence and electron microscopical observations on the amine-accumulating neurons of the Cebus monkey retina. J. Comp. Neurol. 192: 665-685.

Dubocovich, M. L., and N. Weiner (1981) Modulation of the stimulation-evoked release of $3 \mathrm{H}$-dopamine in the rabbit retina. J. Pharmacol. Exp. Ther. 219: 701-707.

Ehinger, B. (1983) Functional role of dopamine in the retina. In Progress in Retinal Research, N. N. Osborne and G. J. Chader, eds., Vol. 2, pp. 213 232, Pergamon Press, New York.

Enroth-Cugell, C., and P. Lennie (1975) The control of retinal ganglion cell discharge by receptive field surrounds. J. Physiol. (Lond.) 247: 551-578.

Famiglietti, E. V., Jr., and H. Kolb (1976) Structural basis for ON- and $\mathrm{OFF}$-center responses in retinal ganglion cells. Science 194: 193-195.

Hedden, W. L., and J. E. Dowling (1978) The interplexiform cell system. II. Effects of dopamine on goldfish retinal neurons. Proc. R. Soc. Lond. Biol. 201: 27-55.

Holmgren, I. (1982) Synaptic organization of the dopaminergic neurons in the retina of the cynomolgus monkey. Invest. Ophthalmol. Vis. Sci. 22: 8-24.

Holmgren-Taylor, I. (1982) Ultrastructure and synapses of the $(3 \mathrm{H})$ dopamine-accumulating neurons in the retina of the rabbit. Exp. Eye Res. 35: 555-572.

Iuvone, P. M., C. L. Galli, C. K. Garrison-Gund, and N. H. Neff (1978) Light stimulates tryosine hydroxylase activity and dopamine synthesis in retinal amacrine neurons. Science 202: 901-902.

Jensen, R. J., and N. W. Daw (1983) Towards an understanding of the role of dopamine in the mammalian retina. Vision Res. 23: 1293 1298.
Kebabian, J. W., and D. B. Calne (1979) Multiple receptors for dopamine. Nature 227: 93-96.

Kramer, S. G. (1971) Dopamine: A retinal neurotransmitter. I. Retinal uptake, storage and light stimulated release of $3 \mathrm{H}$-dopamine in vivo. Invest. Ophthalmol. Vis. Sci. 10:438-452.

Laufer, M., K. Negishi, and B. D. Drujan (1981) Pharmacological manipulation of spatial properties of S-potentials. Vision Res. 21: $1657-1660$.

Magistretti, P., and M. Schorderet (1978) Differential effects of benzamides and thioxanthenes on dopamine-elicited accumulation of cyclic AMP in isolated rabbit retina. Naunyn-Schmiedebergs Arch. Pharmacol. 303: 189-191.

Makman, M. H., B. Dvorkin, and P. N. Klein (1982) Sodium ion modulates D2 receptor characteristics of dopamine agonist and antagonist binding sites in striatum and retina. Proc. Natl. Acad. Sci. U. S. A. 79: 4212-4216.

Negishi, K., and R. D. Drujan (1979) Reciprocal changes in center and surrounding $S$ potentials of fish retina in response to dopamine. Neurochem. Res. 4: 313-318.

Nelson, R., and H. Kolb (1983) Synaptic patterns and response properties of bipolar and ganglion cells in the cat retina. Vision Res. 23: 1183-1195.

Nelson, R., E. V. Famiglietti, Jr., and H. Kolb (1978) Intracellular staining reveals different levels of stratification for on- and offcenter ganglion cells in cat retina. J. Neurophysiol. 41: 472-483.

Neyton, J., M. Piccolino, and H. M. Gerschenfeld (1982) Dopamine (DA) and drugs that increase intracellular cyclic AMP decrease junctional communication between L-horizontal cells. Soc. Neurosci. Abstr. 8: 132.

Parkinson, D., and R. R. Rando (1983) Effect of light on dopamine turnover and metabolism in rabbit retina. Invest. Ophthalmol. Vis. Sci. 24: 384-388.

Pourcho, R. G. (1982) Dopaminergic amacrine cells in the cat retina. Brain Res. 252: 101-109.

Proll, M. A., and W. W. Morgan (1982) Adaptation of retinal dopamine neuron activity in light-adapted rats to darkness. Brain Res. 241: 359-361.

Reading, H. W. (1983) Dopaminergic receptors in bovine retina and their interaction with thyrotropin-releasing hormone. J. Neurochem. 41: $1587-1595$.

Sterling, P. (1983) Microcircuitry of the cat retina. Annu. Rev. Neurosci. 6: $149-185$.

Straschill, M., and J. Perwein (1975) Effects of biogenic amines and amino acids on the cat's retinal ganglion cells. In Golgi Centennial Symposium Proceedings, M. Santini, ed., pp. 583-591, Raven Press, New York.

Teranishi, T., K. Negishi, and S. Kato (1984) Regulatory effect of dopamine on spatial properties of horizontal cells in carp retina. $J$. Neurosci. 4: 1271-1280.

Thier, P., and V. Alder (1984) Action of iontophoretically applied dopamine on cat retinal ganglion cells. Brain Res. 292: 109-121.

Vaney, D. I., W. R. Levick, and L. N. Thibos (1981) Rabbit retinal ganglion cells. Receptive field classification and axonal conduction properties. Exp. Brain Res. 44: 27-33.

Ventura, A. M., W. L. Klein, and F. G. de Mello (1984) Differential ontogenesis of D1 and D2 dopaminergic receptors in the chick embryo retina. Dev. Brain Res. 12: 217-223.

Watling, K. J., and J. E. Dowling (1981) Dopaminergic mechanisms in the teleost retina. I. Dopamine-sensitive adenylate cyclase in homogenates of carp retina: Effects of agonists, antagonists and ergots. J. Neurochem. 36: 559-568.

Watling, K. J., and L. L. Iversen (1981) Comparison of the binding of $\left[{ }^{3} \mathrm{H}\right]$ spiperone and $\left[{ }^{3} \mathrm{H}\right]$ domperidone in homogenates of mammalian retina and caudate nucleus. J. Neurochem. 37: 1130-1143.

Watling, K. J., J. E. Dowling, and L. L. Iversen (1979) Dopamine receptors in the retina may all be linked to adenylate cyclase. Nature 281: $578-580$. 